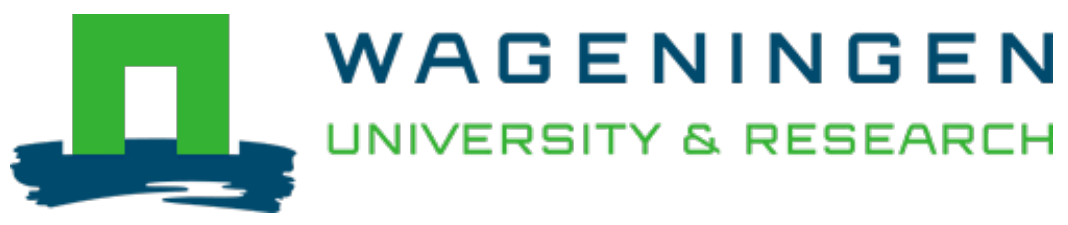

\title{
De-/re-agrarianisation: Global perspectives
}

Journal of Rural Studies

Hebinck, Paul

https://doi.org/10.1016/j.jrurstud.2018.04.010

This article is made publicly available in the institutional repository of Wageningen University and Research, under the terms of article $25 \mathrm{fa}$ of the Dutch Copyright Act, also known as the Amendment Taverne. This has been done with explicit consent by the author.

Article $25 \mathrm{fa}$ states that the author of a short scientific work funded either wholly or partially by Dutch public funds is entitled to make that work publicly available for no consideration following a reasonable period of time after the work was first published, provided that clear reference is made to the source of the first publication of the work.

This publication is distributed under The Association of Universities in the Netherlands (VSNU) 'Article $25 \mathrm{fa}$

implementation' project. In this project research outputs of researchers employed by Dutch Universities that comply with the legal requirements of Article $25 \mathrm{fa}$ of the Dutch Copyright Act are distributed online and free of cost or other barriers in institutional repositories. Research outputs are distributed six months after their first online publication in the original published version and with proper attribution to the source of the original publication.

You are permitted to download and use the publication for personal purposes. All rights remain with the author(s) and / or copyright owner(s) of this work. Any use of the publication or parts of it other than authorised under article $25 \mathrm{fa}$ of the Dutch Copyright act is prohibited. Wageningen University \& Research and the author(s) of this publication shall not be held responsible or liable for any damages resulting from your (re)use of this publication.

For questions regarding the public availability of this article please contact openscience.library@,wur.nl 
Editorial

\section{De-/re-agrarianisation: Global perspectives}

\section{A R T I C L E I N F O}

\section{Keywords:}

Deagrarianisation

Reagrarianisation

Repeasantisation

Rural development

Family farming

Agriculture

Political economy

Dichotomies

Assemblages

\begin{abstract}
A B S T R A C T
This article introduces a special issue that is dedicated to a critical inquiry of the deagrarianisation and depeasantisation theses. It sets the scene for the contributions that are included in the special issue and sketches the themes that are covered. An analysis of this kind is important because ultimately, it is concerned with key agrarian questions about the future of family farming, food security and sovereignty, land-based livelihoods and rural areas as a whole.

The contributions to this special issue explore ways of conceptualising agriculture and the rural. For some, a leading question is whether and how processes of repeasantisation and re-agrarianisation are relevant to robust agrarian pathways. Other contributions prefer relational approaches and analyse transformation processes using concepts like 'territory' and '(re- and/or de-)territorialisation', 'landscape' and 'assemblages' to examine processes of change in the rural domain. They share the premise that it is worthwhile exploring the underlying dynamics of these processes as real and representing agrarian pathways that hold the promise of a dynamic agrarian future and vibrant countrysides. The articles also agree on the need to go beyond understanding development as unilinear and dichotomous. They all engage critically with the rather predominant view that deagrarianisation and depeasantisation are inevitable, evolutionary outcomes of the ongoing processes of agrarian transformation.
\end{abstract}

1. Setting the scene: the deagrarianisation and depeasantisation theses and the future of the rural and the agrarian

Processes of deagrarianisation and depeasantisation are theorised as inevitable outcomes of past and contemporary processes of agrarian transformations. Global, capitalist expansion has restructuring effects on farming, the way farming is practised, the composition of the family and the provision of (family) labour; the intergenerational transfer of farm assets; urban-rural interactions; the natural environment and landscape; and the supply and provisioning of food. Scholars predict the demise of what is referred to in the policy and scholarly literature as 'small-scale' or 'smallholder farming', 'family farming' or 'peasant farming'1 (Bernstein, 2001, 2016; Rigg, 2006; Araghi, 1995; Hobsbawm, 1994). Globalisation and neoliberalism are said to work against or at least complicate sustainable agrarian pathways that revolve around family farming (Suess-Reyes and Fuetsch, 2016; Woods, 2014; Escobar, 2010; Akram-Lodhi and Kay, 2009). The expansion of capitalism on a global scale continuously (re)shapes agricultural production and reproduction processes and investment and consumption patterns, affecting the forces at work at the level of the farm, family and rural and land-based livelihoods to the extent that the reproduction of family farming is jeopardised. As a result, family farming and any nonor pre-capitalist forms of production are on a linear path to extinction and destined to be subsumed by capital (Bernstein, 2001). Some even call for rural development pathways that no longer place small-scale agriculture at the centre (Sender and Johnston, 2004; Bernstein, 2016).

Deagrarianisation is broadly referred to in the scholarly literature as a process producing social, material and biophysical conditions that are not conducive to the reproduction of agrarian and land-based livelihoods. Strictly agriculture-based modes of livelihood will become rare in the near future (Bryceson, 1996, 2002a; 2002b). Agriculture increasingly provides insufficient income and employment opportunities, pushing rural people to work off-farm, to migrate to the cities in search of work, and/or to engage in marginal 'subsistence' agriculture which is doomed to render enduring rural poverty from which people only wish to escape. Deagrarianisation manifests in an occupational shift, ultimately resulting in a further reduction of the share of small-scale or family farming in total agricultural production. The roles and functions of family farming in the further development and enrichment of the landscape diminishes similarly in scale and intensity. Depeasantisation, on the other hand, manifests in situations where farming is predominantly becoming organised by corporate entities (i.e. plantations) or by medium-scale, commercial, entrepreneurial forms of farming. Depeasantisation entails the disappearance of the peasantry whose livelihoods are tied to the land, or their being dispossessed and replaced by outgrowers and contract farming schemes, or corporate large-scale

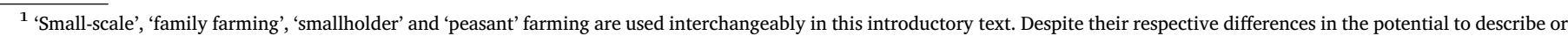
to analyse, these notions convey that rural production is predominantly organised through employing family labour on family land.
} 
farming operations. Depeasantisation also means that the resource base of (any form of) farming is increasingly disconnected from the locality, from activities on- and off-farm and the immediate natural environment. Capital (i.e. agribusiness companies) increasingly structures agrarian relations, determining how farming is and should be done, what resource-use efficiency is, how added value is distributed and how rural incomes are constituted.

The confluence of deagrarianisation and depeasantisation processes offers substantial scope for critical engagement with the underlying conceptualisation of agrarian transformation processes. This allows, in turn, possibilities for alternative frameworks and an exchange of ideas about more optimistic and robust scenarios of what the future could hold for the rural and the agrarian. Is there, indeed, little place and scope for family farms and peasant forms of farming in the future? Is indeed agriculture and the practice of farming increasingly modelled according to agro-industrialism and associated interests? What scope is there for new relations between production and consumption, producers and consumers; will the agrarian landscape be progressively subjected to neoliberal policies; will rural livelihoods always be severely stressed and is the opportunity for a full-time involvement in agriculture open to a few only?

Considering global tendencies in the agriculture and rural development process, we cannot, realistically, deny that deagrarianisation is a real trend; nor can we refute that processes of rural livelihood diversification occur, or that the continuity of (family) farming is challenged. There are many processes at play that push rural people off the land to a marginal life in cities. The concentration of corporate power up- and downstream from the farm is increasing. There is thus no doubt that capitalist expansion poses new threats and continuously forces us to rephrase existing sets of agrarian questions (McMichael, 2013; Akram-Lodhi and Kay, 2009, 2010a; 2010b; Lang, 2010; Bernstein, 1997, 2004; 2010b) and that it simultaneously generates multi-faceted agrarian crises that challenge the continuity of farming and the strengthening of rural livelihoods (Van der Ploeg, 2006, 2010a; HoltGiménez and Altieri, 2012; Patel, 2007; Woods, 2007, 2014). Do we agree, however, with the éminence grise of agrarian political economy Henry Bernstein that the original agrarian question of capital has been solved, but that the agrarian question of the reproduction and quality of life of (rural) labour has largely been left unresolved?

This special issue calls such and related interpretations of agrarian transformation processes - and the images these hold for the future into question. These transformations and the emergence of new crises (i.e. environmental, financial, enduring poverty) urge us to be both alert to and critical of how the global expansion of capitalism and associated trends of globalisation impact on (family) farming and rural development, and more specifically, the view that deagrarianisation and depeasantisation are indeed the inevitable structural outcomes of development. We are in the happy circumstance that the rather bleak future of a deagrarianised rural sector and depeasantised agriculture is not widely experienced. Rural people continue to live and work in the rural domain, actively (re)assembling their lives and social and natural resources to maintain the vitality of their countryside and living in accordance with locally and culturally embedded strategies. They do this by interacting in many different ways with their (trans)local environment, attempting to create markets they themselves can control and enriching resources relatively autonomously. The contributions to this special issue are all vibrant testimonies of the struggles and attempts to rework the said restructuring effects of capitalism, globalisation and neoliberalisation. For many practitioners (Wegner and Zwart, 2011; Samberg et al., 2016), activists (Borras, 2016; Rosset et al., 2006) and academics (Van der Ploeg, 2008, 2016; De Schutter, 2011) and to a degree also policymakers, family or peasant farming is worth supporting, worth fighting and arguing for. Peasant or smallholder farming continues to represent an agrarian pathway that would secure a viable and dynamic countryside. The majority of these farms are located in the global South and continue to be important in the global North as well (Hazell et al., 2010; Wegner and Zwart, 2011; Lowder et al., 2016). The quantitative and qualitative importance of family farming is significant, supporting roughly one-third of the global population (Samberg et al., 2016). Recent Food and Agricultural Organisation (FAO) estimates indicate that about $53 \%$ of all agricultural land is part of family farms (Graeub et al., 2016; Lowder et al., 2016). Due to their labour intensity, family farms provide employment to much larger numbers of people per unit of farmland than larger scale capital-intensive farming units. Family farmers are arguably also more resource efficient and productive per unit of farm land when compared with corporate farming (Lowder et al., 2016: 2; Van der Ploeg, 2008, 2017). Accordingly, family farming presents considerable scope for the expansion of employment in agriculture and the rural economy (Milone and Ventura, 2010), underlining the quantitative and qualitative significance of family farming from a global rural livelihood and wellbeing perspective.

The continuity of family farming and the rural development processes that are driven by family farming, despite the said global tendencies of deagrarianisation and depeasantisation, raises a number of questions about whether these processes are inevitable, evolve linearly and manifest globally in similar ways and with similar intensities. Or do we simultaneously witness, next to and in contrast with deagrarianisation and depeasantisation, processes of re-agrarianisation and repeasantisation? If so, is family or peasant farming sufficiently robust, resistant and innovative to counter these global trends and rework their effects by creating new, more vigorous forms of resource utilisation, depending on what kinds of interaction between the social and natural resources rural people have at their disposal (Woods, 2014; Van der Ploeg, 2013, 2008; Snipstall, 2015; Suess-Reyes and Fuetsch, 2016)?

This special issue brings together a number of original, researchbased articles debating these questions. Some contributions revolve around analyses of peasantry, peasant farming and repeasantisation. Other contributions prefer relational approaches and analyse transformation processes using concepts such as 'territory' and '(re- and/or de-) territorialisation', 'landscape' and 'assemblages' to examine processes of change in the rural domain. What the contributions have in common is the premise the premise that it is worthwhile exploring the underlying dynamics of these processes as real and important for robust agrarian pathways that hold the promise of a dynamic agrarian future and vibrant countrysides.

This introduction continues with a brief depiction of how four major global trends playing a '(re)structuring' role in agrarian transformation do so in such a way that deagrarianisation and depeasantisation are among the outcomes. I then present a condensed summary of the various theoretical positions and the kinds of critical question that these raise for further scrutiny. I then work towards summarising the major themes addressed in this special issue.

\section{Global tendencies and agrarian questions}

There is consensus that the interplay between four major global trends (re)shapes processes of agriculture and rural development, leading in turn to new agrarian questions calling for new analytical perspectives: (1) family farming is under pressure; (2) the 'squeeze on agriculture' is intensifying; (3) agriculture is increasingly industrialising; and (4) there is an intense competition and struggle for land.

\subsection{Family farming dynamics}

Globally, the share of family farming in the agricultural use of land has historically been declining gradually, but persistently (Hobsbawm, 1994; Araghi, 1995; Bernstein, 2010a,b). This decline is associated with the emergence of a global agricultural division of labour. Spurred by the worldwide expansion of capitalism and the development of capitalist agriculture in the form of plantations and mega farms, a world 
market for agricultural commodities came into being, which has rapidly expanded - notably since the 1950s (Van der Ploeg, 2010a; Bernstein, 2016; McMichael, 2013). More recently, the balance between family farming and corporate, capitalist farming has been further tipped in favour of the latter, through 'land grabbing' (Edelman et al., 2013). Equally significant is the expansion and intensification of outgrower schemes and contract farming (Hall et al., 2017) which results in smallholder family farms as independent units being more vertically but firmly - integrated into particular commodity chains that are managed and controlled by corporate companies. Outgrower schemes and contract farming increasingly blur the distinction between family and corporate farming (Oya, 2012; Veldwisch, 2015).

The role of the state and the neoliberalisation of the economy cannot be omitted here. The state's retreat from the organisation of agricultural production and, more importantly, the reorientation of agricultural policies away from the provision of state-led, pro-poor agricultural support for family farming and towards giving more prominence to the market (Stiglitz, 1998, 2002; Harvey, 2005) is highly significant in many ways. There is consensus among development and political economists that neoliberalism created conditions that substantially increased the economic risks associated with farming, negatively affecting many farm operations and land-based livelihoods. The structural adjustment policies and austerity measures imposed on the global South by the Bretton Woods institutions (the IMF, the World Bank) during the 1990s not only curtailed state support for family farming but also reduced the stability of markets, which became significantly more volatile (Stiglitz, 1998; Kydd and Dorward, 2001; Ellis, 2006). The state's repositioning has also narrowed the political avenue for family farmers to seek protection for their rights to land, access to markets and fair commodity prices (Hazell et al., 2010; Borras and Franco, 2010).

'Internal' relations of production, such as demographic changes, are significant for the reproduction of family farming. The 'greying' of farming populations and the associated exit from farming by the youth threatens the intergenerational transfer of knowledge and farm assets. Whilst the average farm size has been rising in the European Union by about 4\% between 2005 and 2010 (Suess-Reyes and Fuetsch, 2016), it has been declining in the South (Lowder et al., 2016). The small size of farms leads to questions about the viability of family farms and whether they continue to provide for sustainable rural livelihoods and to provide raw materials for agro-processing. The shrinking farm size in the global South is mainly ascribed to processes of subdivision and intergenerational redistribution of assets, whilst the grabbing of land for large-scale agricultural production and nature conservation further imposes limits for expansion into new areas.

The youth question has emerged over the years as an important agrarian question. Globally, youth unemployment has been on the rise (ILO, 2010, 2016). Several authors have documented the growing army of young, unemployed people, many of them rural migrants to urban areas. Initially, youth unemployment was largely associated with urban environments (White, 2012a, 2012b) but it is becoming more prominent in rural areas as youth often refuse to provide their labour in support of the family farm (Hull, 2014; Chauveau and Richards, 2008). It would appear that young people growing up on family farms are rejecting the prospect of making the same marginal living as their parents (du Toit and Neves, 2014). Their aspiration for a better life motivates their exodus from family farms (Funahashi, 1996; Rigg and Nattapoolwat, 2001; Proctor and Lucchesi, 2012; Ahaibwe et al., 2013; Bezu and Holden, 2014; Choudhary and Choudhary, 2013; Ramisch, 2014). Li (2009) has argued that it is particularly from subsistence agriculture, pursued in isolated villages far away from modern infrastructure, that young rural people are eager to escape. However, the aspirations of youth who do wish to continue farming or to start farming are often frustrated by the concentration of land in the hands of elites and the older generations (Gilfoy, 2015; Peters, 2013; Chauveau and Richards, 2008; Chinsingwa and Chasukwa, 2012). Land grabbing, the pressure on agricultural incomes, the declining number of young people entering farming mixed with the rejection of an agrarian lifestyle by a new generation (Leavy and Hossain, 2014; Ramisch, 2014; White, 2012a, 2012b; Twyman et al., 2004), are all aspects of the youth question.

\subsection{The on-going squeeze on agriculture}

A significant trend associated with globalisation is that a limited number of globally operating agro-industrial firms have gradually gained more control over the performance of agriculture across many sites and places. This concentration of power takes place up- and downstream of the farm and occurs irrespective of farm type, size, location or farming system. The production and distribution of added value in agricultural commodity chains has thus progressively been shifting away from primary production units to up- and downstream corporate entities (George, 1979; Bernstein, 1996, 2013; Bernstein and Campling, 2006; Patel, 2007; Van der Ploeg, 2008, 2010a,b; Clapp, 2016). This process is also framed by many as 'accumulation by dispossession' - an issue to which we will return. The process has brought about a 'squeeze on agriculture', which refers to the ongoing narrowing of margins in primary production: increases in the cost of production outstrip increases in the price of farm commodities (Marsden, 1998, 2003; Van der Ploeg, 2008, 2010a). At country level, low agricultural commodity prices on global markets are transmitted to the domestic market through trade liberalisation policies that are regulated by World Trade Organisation agreements. The effect has been a decline in agricultural incomes worldwide. The squeeze is also a major driving force for an ongoing scale enlargement in the global North (Lowder et al., 2016) but also in selected countries of the South, notably the BRICS (Brazil, Russia, India, China, and South Africa) countries and middleincome countries (MICs) (Edelman et al., 2013; Cousins et al., 2018). The 'rat race to the bottom', as Marsden (2003) describes the impact of the squeeze, has similarly and certainly intensified global competition between producers, regions and countries, spurring and deepening processes of social differentiation.

\subsection{Agro-industrialisation}

Agriculture is increasingly being industrialised, which has brought about a disconnect between farming, nature and locality (Van der Ploeg, 2008, 2010a; 2010b, 2016; Gliessman, 2012). Growth factors provided by 'nature' are increasingly being replaced by artificial factors generated by means of industrial processes. This has made farming increasingly and significantly dependent on external inputs, new technology, expert knowledge and industrial and financial capital. All of these are commoditised factors of production and they not only raise the cost of production but also make it more rigid, thus contributing to the squeeze on farm margins. Control over land, labour and capital by corporate structures is fundamentally different from that in family or peasant farming (Van der Ploeg, 2010b; Hirsch, 2012) with the result that their dependency on external resources is different. With the further expansion of agro-industrial farming and contract farming, decisions about how to use these factors of production are increasingly taken in boardrooms far removed from the producers and the land on which crops are grown and livestock is reared (Van der Ploeg, 2010b; Hirsch, 2012).

\subsection{Large-scale land acquisitions}

Large-scale land acquisitions have received substantial attention in recent years (Deininger, 2011; Deininger and Byerlee, 2011, 2012; Zoomers, 2010; Edelman et al., 2013). This phenomenon is also framed as 'grabbing' and occurs at a global scale (Borras and Franco, 2013; Borras et al., 2011, 2012; De Schutter, 2011; Fairhead et al., 2012; Van der Ploeg et al., 2015). Land grabbing is clearly associated with the 
corporatisation of agriculture and the ongoing process of agro-industrialisation. As land is increasingly commoditised (Bernstein and Woodhouse, 2001; Peters, 2013; Hirsch, 2012), land changes in meaning and usage. New land markets have developed (Colin and Woodhouse, 2010; Otsuka and Place, 2001) and the registration of land titles to individuals or groups has facilitated land deals. In the global South, where land rights are often uncodified, large-scale land acquisitions have forced many people to vacate land, often without consideration for either their cultural rights to land or proper compensation. Communal land rights and its related resources are frequently ignored or abused (Margulis et al., 2013). In the northern and western parts of Europe, land acquisitions have made land more expensive and machine-servicing more costly (Van der Ploeg et al., 2015; Van der Ploeg, 2008).

Corporate interest in farmland is fuelled by speculation and the expectation that land prices will rise. The rising importance of 'flex crops' is also significant in explaining the global interest in land by corporate capital groups and local elites. Flex crops have multiple uses (food, feed, fuel, fibre, industrial material, etc.) that can be flexibly interchanged in response to market prices and other incentives, such as carbon credits (Borras et al., 2016: 2). Flex crops can also be profitably produced on large, mega farms that can swiftly respond to the increased global demand for flex crops, such as maize and sugar.

Food retail patterns are changing rapidly in favour of supermarkets. The search for greater economic efficiency and profits by shareholders and food empires (Van der Ploeg, 2010a,b, 2008) has in turn driven the expansion of 'corporate super farms'. Supermarkets favour 'networks of preferred suppliers' which significantly reduce transaction costs in the value chain and increase reliability of supply in terms of quantity, quality and timing (Proctor and Lucchesi, 2012). Family farms are usually not and prefer not to be part of these retail networks (Weatherspoon and Reardon, 2003; Reardon et al., 2007, 2012; Louw et al., 2007; Manyelo et al., 2015).

The interplay between the expansion of a world market for agricultural commodities, land grabbing, problems with intergenerational transfers of family farm assets, the ongoing squeeze on farm income and the agro-industrialisation of farming drives agrarian transformations that are framed as 'accumulation by dispossession' (Bernstein, 1996, 2010a,b; Harvey, 2005, 2009; Glassman, 2006). Accumulation by dispossession is also taken to mean the ongoing commoditisation of goods that were not previously perceived as part of the global circuits of exchange. Harvey $(2005,2009)$ and Glassman (2006) advance the argument that once commodities are incorporated in markets more generally they are capitalised, meaning controlled by capital groups (e.g. speculators, trading companies, supermarket chains). Commoditisation, or rather, accumulation by dispossession, is directly associated with capitalist competition but also with the loss of control over the distribution of the added value that is realised when goods are traded by independent producers (e.g. smallholders, harvesters of non-timber forest products). These forms of accumulation by dispossession and land concentration are seen as a vehicle for major agrarian transformations that inevitably lead to deagrarianisation and depeasantisation as well as the further marginalisation of rural classes of labour (Bernstein, 2010b and many other of his publications). Whilst the underlying dynamics of accumulation by dispossession may vary across the globe, the outcomes are rather similar: land dispossession and abandonment of farming as a source of livelihood. The dispossessed are turned either into wage labourers, farm workers or landless proletarians who face a 'jobless non-agrarian future' (du Toit and Neves, 2014).

Globalisation certainly has intensified existing contradictions and continuously produces new ones. Competition for land and other resources has increased and control over decision-making about which resources to use, how and at what environmental expense has changed dramatically. Globalisation has increased the global flow of commodities and, embedded in trade liberalisation policies, intensifies competition between agricultural producers across the globe.
The sequel to globalisation and the neo-liberalisation of agrarian policies is not just the emergence of problems and crises; new development opportunities have also arisen for the social actors involved (e.g. farmers, agribusiness, traders, consumers, bankers). The practices of social actors have created new material realities that enhance space for 'local' development: newly emerging or 'nested' markets, new landuse practices, redefined resources and new relations between production and consumption, producers and consumers, and so on. This does not mean that the accumulation of wealth and power accompanied by processes of dispossession, widening regional and social differentiation, social inequalities and increased levels of poverty should be ignored. Neoliberalism is interpreted here as not necessarily fixed, disciplining and constraining (Harvey, 2005, 2007) but simultaneously as a situation that also creates new opportunities at the local level (Cheshire and Woods, 2013; Marsden, 2016; Pasmans and Hebinck, 2017). The 'local' is not just a place of resistance, but also one where creativity and robust solutions to everyday problems and issues unfold.

Globalisation along these lines of thought is then about extended flows of commodities (e.g. capital, knowledge, labour and technology) across the globe that generate locally specific 'interconnected, but not homogenous, set(s) of projects' (Tsing, 2000: 353). The concrete manifestations of globalisation are not uniform but vary considerably in intensity and place. The expanded flow of commodities is produced under diverse socio-material conditions, varying social relations of production and social forms of production and reproduction. Globalisation thus may generate specific global tendencies but also countertendencies (Arce and Long, 2000), and continuous local-global interactions and connections creating, in turn, new assemblages (Li, 2007, 2014; Anderson and McFarlane, 2011; Woods, 2015).

The tendencies and counter-tendencies and the locally specific expressions of globalisation are framed in this special issue as processes of 'deagrarianisation' and 'depeasantisation', but also 'agrarianisation', 're-agrarianisation', 'repeasantisation' or '(re) territorialisation'. These represent different and contrasting agricultural and rural development pathways that are sustained and legitimised by internally consistent but competing paradigms. The need to deal with how these contradicting processes are debated and looked at methodologically, is an important part of the justification for this special issue.

\section{Debating deagrarianisation and agrarian transformations}

Debating and critiquing deagrarianisation and depeasantisation requires being critical of approaches and perspectives that assert these as inevitable outcomes of capitalist development, globalisation and the neoliberalisation of the economy. This special issue brings together a set of papers sharing the perspective that understanding the social and material dimensions of rural development and agriculture requires a non-theological and empirically grounded perspective. This entails - for the sake of argument - moving away from strands of political economy (Akram-Lodhi and Kay, 2010a, 2010b; Bernstein, 2001, 2010a,b; McMichael, 2013; Borras, 2009; Boltvinik and Mann, 2016). Economic historians argue similarly that the peasantry is, or will soon be, gradually disappearing (Hobsbawm, 1994; Peemans, 2013; Vanhaute, 2011, 2012; Araghi, 1995; Wallerstein, 1974) to be replaced by a new breed of rural entrepreneurs who are able to withstand global competition for land, capital and labour; those that survive the rat race to the bottom. Many scholars are sceptical about the role of peasants in global food provisioning (e.g. Bernstein, 2001, 2010a,b, 2014), arguing that the peasant way of life is doomed to disappear (see also McMichael, 2008, 2012). This is not because of peasant backwardness as Bernstein rightfully argues: "Peasants" become petty commodity producers in this sense when they are unable to reproduce themselves outside the relations and processes of capitalist commodity production when the latter become the conditions of existence of peasant farming and are internalized in its organisation and activity' (Bernstein (2001): 29). The increasingly multispatial character of rural livelihoods (Bryceson, 2002a, 2002b; Ellis, 
2000a, 2000b; Francis, 2000) serves as evidence to support the argument that independent reproduction is problematic and involvement in other economic sectors and spaces is a necessary condition for survival. Migrant income, remittances and state transfers have, for many rural families, become the predominant monetary sources of income, replacing income from rural and land-based activities. For others (Eastwood et al., 2006), deagrarianisation and depeasantisation are treated as intrinsic to economic development. It is quite commonly accepted that (economic) development implies a declining share of agriculture in both workforce and output (Eastwood et al., 2006): a trend from which economies and societies apparently cannot escape.

Despite ideological differences in their positioning, agrarian political economists and classical economists seemingly share the view that the logic of accumulation and development dictates that, once deagrarianisation and depeasantisation have been set in motion - through dispossession or competition, capitalist expansion, demographic changes and forced removals - rural people are progressively disconnected from the land; there is no way back. A return to the land to start farming (again) is not considered to be a serious option for development. Repeasantisation is deemed impossible as peasants are doomed to disappear. Nonetheless, continuous agrarianisation, implying that the agricultural and rural sector remains important for rural livelihoods, is key to understand and to explore.

South East Asian experiences, documented by De Koninck and Rousseau (2012) show that the employment-retaining capacity of the agriculture sector has remained significant over the years. Farming activities alone are insufficient to keep people on the land, but pluriactivity is spreading (Rigg et al., 2016; see also Kinsella et al., 2000; Oostindie, 2015). Yet agriculture has shown a remarkable resilience, and the deagrarianisation of the countryside is not proceeding as rapidly and as intensely as expected. For nearly half a century since 1961, indices of net agricultural and food production per capita in South East Asia has outpaced global trends. Hirsch (2012) points out that a significant part of the population in South East Asian countries continues to be rural in location and agricultural in identity. Moreover, deliberate transformations, analytically captured by Oostindie in this special issue as 'multifunctional farming', require not just rethinking classificatory schemes (i.e. what is a farm) but also rethinking what we mean by agriculture and how farms (are to be) develop (ped). In the Netherlands and other parts of rural Europe and the US, we note the tendency to extend high-tech precision farming, high input and large-scale farming (i.e. economies of scale).

An analytically and empirically more significant tendency is that farmers are broadening the economic base of their farms by becoming multifunctional farms - that is, by combining agriculture in meaningful and coherent ways with other activities like quality production and agro-tourism, often in association with cutting monetary expenditure and reducing inputs (i.e. economies of scope rather than scale) (see also Oostindie, 2015; Roep and Van der Ploeg, 2003; Van der Ploeg, 2017). Zimbabwean and South African experiences show that re-agrarianisation has taken root and presents itself as a serious and vibrant agrarian pathway that is based on capital sources from elsewhere (e.g. gold panning, migrant wages, pensions), and that strengthens and, in some cases, expands agricultural production activities. Typically, the state is absent in these processes.

In Africa and elsewhere in the global South, agriculture as the basis of rural livelihoods is increasingly being squeezed and challenged because of land issues and conflicts as well as chaotic markets, which in turn fuel migration to the city in the hopes of earning additional income to feed back to homes in the rural area. This trend is well documented in the literature about the global South (Bryceson and Jamal, 1997; Bryceson et al., 2000; Bryceson, 1996, 2002a; 2002b; Francis, 2000; Ellis, 2000a,b; Zoomers, 2001; Rigg, 2005, 2006; Rigg et al., 2016; Hirsch, 2012). However, a complete disconnect from the rural base does not occur. Rural people continue to (re)engage in a range of activities and forms of agriculture (Rasmussen and Reenberg, 2015;
Dzanku, 2015). These activities, and the socio-material relations in which they are embedded, are not well understood and, more importantly, inadequately conceptualised. Based on research in the Philippines (Wolfram Dressler, Will Smith and Marvin Montefrio), The Netherlands (Henk Oostindie), South Africa (Sheona Shackleton and Paul Hebinck; Paul Hebinck, Nosiseko Mtati and Charlie Shackleton), Turkey (Murat Öztürk, Joost Jongerden and Andy Hilton), Japan (Shuji Hisano, Motoki Akitsu and Steven McGreevy) and Zimbabwe (Easther Chigumira), these land-use practices are explored and found to be robust and dynamic. These practices, argue the researchers, cannot simply be captured as evidence that deagrarianisation occurs neither as a structural nor as a desired process. Whereas re-agrarianisation or even repeasantisation is not among the Rostowian stages of growth and is a teleological impossibility, the case material from Zimbabwe, South Africa, the Netherlands, the Philippines, Turkey and Japan presented in this issue show that they are real. The papers recount the specificities of processes of ruralisation and the kind of social-material relations rural people develop. The result is a broad concept of the 'new peasantry', one that is rooted in the family farm but nevertheless (often) integrates wage-labour relations and, since it is not bound by agriculture only, transcends the rural-urban division of space. The 'new peasantry' emerges and unfolds (more and more) translocally.

Moreover, the very analyses of the processes of production and consumption, resource enrichment and allocation, marketing and land use practices defy the existing classificatory schemes that are applied in much of the social and natural science literature, grouping and categorising rural people according to class, gender, race or income, and distinguishing agriculture or culture from nature. Broadening these classificatory schemes has consequences for the way we place rural people in the social order. Do we identify agrarian classes based on access to and ownership of land and capital (Bernstein, 1994, 2010a,b; Cousins, 2011; Scoones et al., 2012)? Such an analysis does not necessarily always reflect the complexities of agriculture and rural life. Class analysis tends to obscure important everyday life dynamics, such as alternative practices, and ignores the agency we may attribute to rural people in their attempts to carve out a living under the sometimes extreme conditions generated by globalisation, competition and violence (Long, 2001; Olivier de Sardan, 2006). The social relations of production (and consumption) are not simply based on class relations per se; it is more fruitful - and the papers included here attest to that to conceptualise these as an expression and outcome of process and people's struggle towards greater autonomy, food sovereignty and wellbeing (see also Van der Ploeg, 2008, 2010b; 2013, 2014; Rosset, 2013; Martínez-Torres and Rosset, 2010).

The task of a counter deagrarianisation narrative is to explore other analytical routes that go beyond class distinction and dichotomies such as 'production' and 'consumption' or 'nature' and 'culture'. The contributors to this special issue prefer an ordering that captures the activities of the social actors involved, and how assemblages unfold and give meanings to them. Processes of change do not proceed along preset, linear trajectories, are not homogenous and are not predictable. Instead, development unfolds as chaotic, many-sided, heterogeneous and often contradictory. Similarly, globalisation should not be considered as a top-down process, something that is simply imposed on people and places. Globalisation, instead, is a process that is reproduced through social practices, in and through (trans)local places (Woods, 2007, 2015; McFarlane, 2009). Local actors have the capacity to shape and rework the outcomes of globalisation by capturing, manipulating, resisting and subverting global networks and processes, and by initiating their own translocal connections (Tsing, 2000; Arce and Long, 2000; Long, 2001; Cheshire and Woods, 2013; Woods, 2015). The article on blueberry harvesting in Latvia by Mikelis Grivins and Talis Tisenkopfs demonstrates not only the importance of continuing an agrarian lifestyle but also the harvesters' social struggles to retain control over their produce by orientating their marketing to newly constructed 'nested' markets where the distribution of the added value 
is fairer (Van der Ploeg et al., 2012; Hebinck et al. 2015b; Schneider et al., 2016). Analytically, these markets unfold as negotiated spaces of opportunity for a diverse group of actors who are well capable of defending these spaces against corporate control (see also Mutopo, 2014).

In the contributions to this issue, and to varying degrees of detail, coherent sets of concepts are applied that interpret social and agrarian change as structured (and not determined) by the interactions between human and non-human actors. Assemblage theory, in many ways, theorises firmly the importance of non-linearity and fluidity while integrating and exploring the interactions between human and nonhuman resources (Deleuze and Guattari, 1987; Latour, 2005; De Landa, 2006; Li, 2007, 2014; Umans and Arce, 2014; Woods, 2015). Assemblages are understood as fluid and not fixed, continuously generating new kinds of socio-material space in which different, new and emergent perspectives are created. Each of these perspectives develops, echoes and presents particular views on the future and place of family farming or, more broadly, agriculture in society and rural development in the context of globalisation and the ongoing neoliberalisation of the economy and society.

The analysis of these processes is taken up variously in this collection of articles, each in its own way and with different emphases. Stephen Sherwood, Alberto Arce and Myriam Paredes argue that people's practices, assemblages and their inter-subjectivities in and through food as a site of social-political-material existence and territorialisation require special attention. They do this by exploring how consumption and production are bridged through civic action. Wolfram Dressler, Will Smith and Marvin Montefrio unpack assemblages as having socio-material properties with agentive and productive capacity. They show specifically how indigenous farmers engage the productive capacity of swidden assemblages as the means by which to negotiate the pressures of upland transformations in the Philippines. Paul Hebinck, Nosiseko Mtati and Charlie Shackleton use the notion of landscape assemblage to explore the transformation from a productive landscape to one which largely hinges on consumption. Protecting the reproduction of homesteads unfolds as the dominant land-use discourse, blurring the boundaries between formally designated land-use categories and emblematic of the transformations occurring in many rural areas in the former homelands of South Africa. For Leonardo van den Berg, Dirk Roep, Paul Hebinck and Heitor Teixeira, regenerative agroecology represents a reassembling of nature-culture relations. They specify how farmers enrich resources through forging productive alignments with non-human nature. Nature adds value, they argue, and that allows farmers to farm more autonomously.

This methodological positioning, I argue, allows greater sensitivity for the discovery of new forms and patterns of production and consumption, for the idea of farming with nature, and for rethinking and reconceptualising social categories that shape development in the context of global processes. The agenda that emerges is diverse, but the items revolve around the practices of social actors, and how these actors (re)construct and (re)shape the social and material world around them. Thinking in terms of non-linearity and heterogeneity allows discovering and depicting significant, relevant details of locally and regionally specific manifestations of agrarian transformations. Analyses of the multiple empirical realities globally not only highlight contrasting tendencies and processes, but also show how these resonate with and contribute to enhanced rural livelihoods and wellbeing. Thus while generic processes may operate (see section 2), contrasting responses to globalisation translate into the emergence of diverse agrarian pathways.

Triggered by a variety of processes - a return to the land through land reform and resettlement programmes (Van den Berg et al., 2018; Hebinck and Cousins, 2013; Dekker and Kinsey, 2011; Mutopo, 2011; Scoones et al., 2010; Rosset et al., 2006; Thiesenhusen, 1995), but also the gradual shift of the meaning of land because of commoditisation (Hirsch, 2012; Borras and Franco, 2013), and building on the continuities of holding on to the land of family farmers across the generations (Fay, 2015; Oostindie, 2015) - we witness processes of reagrarianisation and repeasantisation (see also Van den Berg et al., 2018; Nelson and Stock, 2018; Calvário, 2017). The articles by Easther Chigumira on Zimbabwe, Henk Oostindie but also Jan Douwe van der Ploeg about The Netherlands, Murat Öztürk, Joost Jongerden and Andy Hilton about Turkey and Leonardo van den Berg, Dirk Roep, Paul Hebinck and Heitor Teixeira about Brazil elaborate the detail of how and why continuous agrarianisation and repeasantisation occur. Sheona Shackleton and Paul Hebinck for the Transkei in South Africa and Shuji Hisano, Motoki Akitsu and Steven McGreevy for Japan, disclose the dynamics of continuous agrarianisation in the midst of a deagrarianising landscape. This is not just limited to the global South but also manifests in different forms and shapes in Europe and the USA, with or without state and/or society support (e.g. LEADER programmes in the EU; Community Supported Agriculture (CSA) initiatives).

Repeasantisation and the central role of family farming is the analytical answer to the ideas and images of drudgery as well as 'efficientbut-poor' discourses such as those of Schultz (1964) during the 1950s (Van der Ploeg, 2010a, 2013, 2014). Repeasantisation unfolds as the interconnection of processes of people holding on and/or 'returning' to rural and land-based activities, either through inheriting land from kin or otherwise, or through purchasing private land or accessing land through planned and unplanned (e.g. squatting) land reform programmes, with the (re)construction of a social-material infrastructure that allows rural producers to farm and construct livelihoods that are to a degree autonomous. A central aspect is the conversion of human capital into natural - or more precisely - agroecological capital, rather than reliance on the availability of financial capital to purchase assets and advice (Van der Ploeg, 2010a, 2014). The increase of agroecological capital is embedded in a labour and production process that primarily hinges on employing own family labour which is often intensified over time to secure an enhanced livelihood for the family. The family is usually the social unit of farming that strives to enrich and add value to own (ed) resources through their own labour. Altieri and Toledo (2011) exposition of the 'agroecological revolution' conforms with the mode of resource use exhibited in the process of repeasantisation: resources are pre-dominantly retrieved from the ecological environment rather than acquired through market transactions, and production is largely based on and sustained by ecological processes. Leonardo van den Berg, Dirk Roep, Paul Hebinck and Heitor Teixeira in this special issue treat 'farming with nature' as the ultimate translation and expression of repeasantisation and the creation of conditions of autonomy. The association between repeasantisation and agroecology is often made in the literature (Van den Berg et al., 2018; Nelson and Stock, 2018). Agroecology as science, resistance and social movement is nowadays commonly argued for and supported (Mousseau, 2016; Marongwe et al., 2012; Snipstall, 2015; Sevilla Guzmán and Woodgate, 2012; Gliessman, 2012; Holt-Gimenez and Altieri, 2012; Wezel et al., 2009, 2015). Repeasantisation, as an integral part of rural development processes in and over time, will ultimately manifest as generating more rural employment opportunities and enhanced levels of income and self-respect. Repeasantisation evolves into development situations where the size of the agrarian economy, agrarian or agrarian-related activities gradually, but notably, increases (Milone and Ventura, 2010; Milone et al., 2015, 2018).

This then also raises the question of how to conceptualise and unpack agriculture or more accurately perhaps, rural-based activities. Do we stick to conventional understandings of agriculture that conform to the idea that modern agriculture hinges on externally derived inputs, that farming is strictly limited to converting natural resources on the farm into commodities? This is a common thread in the deagrarianisation/depeasantisation literature: agriculture is equal to modern agriculture, large-scale and technologically advanced; a form of agriculture that secures the production and productivity increases required to feed the world. This perspective is what agrarian political economists have in common with many economists, plant breeders and 
agronomists. The tendency to narrowly, restrictively define what constitutes agriculture and rural activities is challenged by the articles included this special issue. They embrace the idea that we need to go beyond agriculture (or cropping and cattle rearing) per se and accept that culture and nature boundaries are blurred in many different ways (see also Croll and Parkin, 1992). There is accumulating evidence that rural livelihoods hinge on more than farming alone (Shackleton and Shackleton, 2015; Vandermeer and Perfecto, 2012; Toledo, 1990). However, not only 'outside' monetary sources like pensions, remittances or migrant labour income play a role but also harvesting from the wild and the natural environment. Farming, or agriculture, entails more than simply growing crops or keeping livestock - this is demonstrated in detail by Paul Hebinck, Nosiseko Mtati and Charlie Shackleton in the article on rural South Africa. The papers by Leonardo van den Berg, Dirk Roep, Paul Hebinck and Heitor Teixeira on Brazil, Easther Chigumira on Zimbabwe, Murat Öztürk, Joost Jongerden and Andy Hilton on Turkey, Wolfram Dressler, Will Smith and Marvin Montefrio on the Philippines and Mikelis Grivins and Talis Tisenkopfs on Latvia clearly point to the analytical advantage of broadening the 'farm' to include the natural environment, utilised through harvesting or otherwise, seeing farming and rural livelihoods as more robust and diverse, and possibly more sustainable in the long run. These (land-use) practices are usually interpreted as merely parts of a safety network used by people to avoid extreme poverty but they can also be conceptualised as examples of a particular manifestation of multifunctional agriculture in the global South. Moreover, the well-rooted cultural meaning that people attach to their environments and its components such as trees, crops and seed (see Cocks et al., 2012, 2017; Hebinck et al. 2015a; Croll and Parkin, 1992) - are an integral part of rural livelihood dynamics.

\section{Acknowledgements}

I am grateful to Editor-in-Chief Michael Woods for his trust in me, and his guidance and support throughout. Without the contributors, who spent their valuable time putting a novel paper together, this issue would not have been so exciting and intellectually stimulating. Over 30 reviewers allocated their precious time to providing detailed and constructive comments. I would also like to acknowledge and thank Jan Douwe van der Ploeg, Wim van Averbeke and Joost Jongerden for their comments on earlier drafts and suggestions for further reading and the framing of the Introduction to this special issue. Inga Norenius took extremely good care of the copy-editing and proofreading.

\section{References}

Ahaibwe, G., Mbowa, S., Lwanga, M., 2013. Youth Engagement in Agriculture in Uganda: Challenges and Prospects, Research Series No 106. Makerere University, Kampala, Economic Policy Research Centre.

Akram-Lodhi, A., Kay, C., 2009. The agrarian question. Peasants and rural change. In: Akram-Lodhi, A., Kay, C. (Eds.), Peasants and Globalization. Political Economy, Rural Transformation and the Agrarian Question. Routledge, London and New York, pp. 3-34.

Akram-Lodhi, A., Kay, C., 2010a. Surveying the agrarian question (part 1): unearthing foundations, exploring diversity. J. Peasant Stud. 37, 177-202.

Akram-Lodhi, A., Kay, C., 2010b. Surveying the agrarian question (part 2): current debates and beyond. J. Peasant Stud. 37, 255-284.

Altieri, M., Toledo, V., 2011. The agroecological revolution in Latin America: rescuing nature, ensuring food sovereignty and empowering peasants. J. Peasant Stud. 38, 587-612.

Anderson, B., McFarlane, C., 2011. Assemblage and geography. Area 43, 124-127.

Araghi, F., 1995. Global depeasantization: 1945-1990. Socio. Q. 36, 337-368.

Arce, A., Long, N., 2000. Anthropology, Development and Modernities: Exploring Discourses, Counter-tendencies and Violence. Routledge, London.

Bernstein, H., 1994. Agrarian classes in capitalist development. In: Sklair, L. (Ed.), Capitalism and Development. Routledge, London, pp. 40-71.

Bernstein, H., 1996. The political economy of the maize filiere'. In: Bernstein, H. (Ed.), The Agrarian Question in South Africa. Frank Cass, London, pp. 120-145.

Bernstein, H., 1997. Agrarian questions then and now. J. Peasant Stud. 24, 22-60.

Bernstein, H., 2001. 'The Peasantry' in Global Capitalism: Who, where and Why? Socialist Register. pp. 25-52.
Bernstein, H., 2004. 'Changing before our very eyes': agrarian questions and the politics of land in capitalism today. J. Agrar. Change 4, 190-225.

Bernstein, H., 2010a. Rural Livelihoods and agrarian change: bringing class back in. In: Long, N., Jingzhong, Y., Yihuan, W. (Eds.), Rural Transformations and Development China in Context: the Everyday Lives of Policies and People. Edward Elgar, Cheltenham, pp. 79-110.

Bernstein, H., 2010b. Class Dynamics of Agrarian Change. Fernwood Publishing Company, Nova Scotia.

Bernstein, H., 2013. Commercial agriculture in South Africa since 1994: 'natural, simply capitalism'. J. Agrar. Change 13, 23-46.

Bernstein, H., 2014. Food sovereignty via the 'peasant way': a sceptical view. J. Peasant Stud. 41, 1031-1063.

Bernstein, H., 2016. Agrarian political economy and modern world capitalism: the contributions of food regime analysis. J. Peasant Stud. 43, 611-647.

Bernstein, H., Campling, L., 2006. Review essay. Commodity studies and commodity fetishism I: trading down. J. Agrar. Change 6, 239-264.

Bernstein, H., Woodhouse, P., 2001. Telling environmental change like it Is? Reflections on a study in sub-saharan Africa. J. Agrar. Change 1, 283-324.

Bezu, S., Holden, S., 2014. Are rural youth in Ethiopia abandoning agriculture? World Dev. 64, 259-274.

Boltvinik, J., Mann, S., 2016. Peasant Poverty and Persistence in the Twenty-first Century: Theories, Debates, Realities and Policies. Zed Books, London, UK.

Borras, S., 2009. Agrarian change and peasant studies: changes, continuities and challenges: an introduction. J. Peasant Stud. 36, 5-31.

Borras, S., 2016. Land Politics, Agrarian Movements and Scholar-activism. International Institute for Social Studies. Erasmus University, The Hague Inaugural Lecture, April 14, 2016.

Borras, S., Franco, C., 2010. Contemporary discourses and contestations around pro-poor land policies and land governance. J. Agrar. Change 10, 1-32.

Borras, S., Franco, J., 2013. Global land grabbing and political reactions 'from below'. Third World Q. 34, 1723-1747.

Borras, S., Franco, J., Isakson, S., Levidow, L., Vervest, P., 2016. The rise of flex crops and commodities: implications for research. J. Peasant Stud. 1-23.

Borras, S., Hall, R., Scoones, I., White, B., Wolford, W., 2011. Towards a better understanding of global land grabbing: an editorial introduction. J. Peasant Stud. 38, 209-216.

Borras, S., Kay, C., Gómez, S., Wilkinson, J., 2012. Land grabbing and global capitalist accumulation: key features in Latin America. Canadian Journal of Development Studies/Revue Canadienne d'études du Développement 33, 402-416.

Bryceson, D., 1996. Deagrarianization and rural employment in sub-saharan Africa: a sectoral perspective. World Dev. 24, 97-111.

Bryceson, D.F., 2002a. The scramble in Africa: reorienting rural livelihoods. World Dev. 30, 725-739.

Bryceson, D.F., 2002b. Multiplex livelihoods in rural Africa: recasting the terms and conditions of gainful employment. J. Mod. Afr. Stud. 40, 1-28.

Bryceson, D.F., Jamal, V., 1997. Farewell to farms: de-agrarianisation and employment in Africa. African Studies Centre, Leiden.

Bryceson, D.F., Kay, C., Mooij, J., 2000. Disappearing Peasantries? Rural Labour in Africa, Asia and Latin America. Intermediate Technology Publications, London.

Calvário, R., 2017. Food sovereignty and new peasantries: on re-peasantization and counter-hegemonic contestations in the Basque territory. J. Peasant Stud. 44, $402-420$.

Chauveau, J.P., Richards, P., 2008. West african insurgencies in agrarian perspective: cote d'Ivoire and Sierra Leone compared. J. Agrar. Change 8, 515-552.

Cheshire, L., Woods, M., 2013. Globally engaged farmers as transnational actors: navigating the landscape of agri-food globalization. Geoforum 44, 232-242.

Chinsingwa, B., Chasukwa, M., 2012. Youth, land grabs and agriculture in Malawi. IDS Bull. 43, 67-77.

Choudhary, H., Choudhary, A., 2013. Why Indian farmers and youth are moving from farming. Popular Khet 13, 60-66.

Clapp, J., 2016. Food, second ed. Polity Press, Cambridge.

Cocks, M., Dold, T., Vetter, S., 2012. God is my forest: Xhosa cultural values provide untapped opportunities for conservation. South Afr. J. Sci. 108, 1-8.

Cocks, M., Vetter, S., Wiersum, K.F., 2017. From universal to local: perspectives on cultural landscape heritage in South Africa. Int. J. Herit. Stud. 1-18.

Colin, J.P., Woodhouse, P., 2010. Introduction: interpreting land markets in Africa. Africa $80,1-13$.

Cousins, B., 2011. What is a 'smallholder'? Class-analytic perspectives on small-scale farming and agrarian reform in South Africa. In: Hebinck, P., Shackleton, C. (Eds.), Reforming Land and Resource Use in South Africa: Impact on Livelihoods. Routledge, London, pp. 86-112.

Cousins, B., Borras, S., Sauer, S., Ye, J., 2018. BRICS, middle-income countries (MICs), and global agrarian transformations: internal dynamics, regional trends, and international implications. Globalizations 15, 1-11.

Croll, E., Parkin, D., 1992. Bush base: Forest Farm. Culture, Environment and Development. Routledge, London.

Deleuze, G., Guattari, F., 1987. A Thousand Plateaus. University of Minnesota Press, Minneapolis.

De Koninck, R., Rousseau, J.F., 2012. Gambling with the Land: the Contemporary Evolution of Southeast Asian Agriculture. NUS Press, Singapore.

De Landa, M., 2006. A New Philosophy of Society: Assemblage Theory and Social Complexity. Continuum, London.

De Schutter, O., 2011. How not to think of land-grabbing: three critiques of large-scale investments in farmland. J. Peasant Stud. 38, 249-279.

Deininger, K., 2011. Challenges posed by the new wave of farmland investment. J. Peasant Stud. 38, 217-247. 
Deininger, K., Byerlee, D., 2011. Rising Global Interest in Farmland: Can it Yield Sustainable and Equitable Benefits? World Bank Publications.

Deininger, K., Byerlee, D., 2012. The rise of large farms in land abundant countries: do they have a future? World Dev. 40, 701-714.

Dekker, M., Kinsey, B., 2011. Contextualizing Zimbabwe's land reform: long-term observations from the first generation. J. Peasant Stud. 38, 995-1019.

du Toit, A., Neves, D., 2014. The government of poverty and the arts of survival: mobile and recombinant strategies at the margins of the South African economy. J. Peasant Stud. 41, 833-853.

Dzanku, F., 2015. Transient rural livelihoods and poverty in Ghana. J. Rural Stud. 40, 102-110.

Eastwood, R., Kirsten, J., Lipton, M., 2006. Premature deagriculturalisation? Land inequality and rural dependency in Limpopo province, South Africa. J. Dev. Stud. 42, 1325-1349.

Edelman, M., Oya, C., Borras, S., 2013. Global Land Grabs: historical processes, theoretical and methodological implications and current trajectories. Third World Q. 34, 1517-1531.

Ellis, F., 2000a. The determinants of rural livelihood diversification in developing countries. J. Agric. Econ. 51, 289-302.

Ellis, F., 2000b. Rural Livelihoods and Diversity in Developing Countries. Oxford University Press, Oxford.

Ellis, F., 2006. Agrarian change and rising vulnerability in rural sub-Saharan Africa. N. Polit. Econ. 11, 387-397.

Escobar, A., 2010. Histories of development, predicaments of modernity: thinking about globalization from critical development studies perspectives. In: Long, N., Ye, J., Yihuan, W. (Eds.), Rural Transformations and Development - China in Context: the Everyday Lives of Policies and People. Edward Elgar, Cheltenham, pp. 25-53.

Fairhead, J., Leach, M., Scoones, I., 2012. Green Grabbing: a new appropriation of nature? J. Peasant Stud. 39, 237-261.

Fay, D., 2015. 'Keeping land for their children': generation, migration and land in South Africa's Transkei. J. South Afr. Stud. 1-15.

Francis, E., 2000. Making a Living: Changing Livelihoods in Rural Africa. Routledge, London.

Funahashi, K., 1996. Farming by the older generation: the exodus of young labor in Yasothon Province. Thailand' Southeast Asian Studies 33, 107-121.

George, S., 1979. Feeding the Few. Corporate Control of Food. Institute of Policy Studies, Washington.

Gilfoy, K., 2015. Land grabbing and NGO advocacy in Liberia: a deconstruction of the 'homogeneous community'. Afr. Aff. 114, 185-205.

Glassman, J., 2006. Primitive accumulation, accumulation by dispossession, accumulation by 'extra-economic' means. Prog. Hum. Geogr. 30, 608-625.

Gliessman, S., 2012. Agroecology: growing the roots of resistance. Agroecology and Sustainable Food Systems 37, 19-31.

Graeub, B., Chappell, M., Wittman, H., Ledermann, S., Kerr, R., Gemmill-Herren, B., 2016. The state of family farms in the world. World Dev. 87, 1-15.

Hall, R., Scoones, I., Tsikata, D., 2017. Plantations, outgrowers and commercial farming in Africa: agricultural commercialisation and implications for agrarian change. J. Peasant Stud. 1-23.

Harvey, D., 2005. A Brief History of Neoliberalism. Oxford University Press.

Harvey, D., 2007. Neoliberalism as creative destruction. Ann. Am. Acad. Polit. Soc. Sci. 610, 21-44.

Harvey, D., 2009. The 'new' imperialism: accumulation by dispossession. Social. Regist 40, 40.

Hazell, P., Poulton, C., Wiggins, S., Dorward, A., 2010. The future of small farms: trajectories and policy priorities. World Dev. 38, 1349-1361.

Hebinck, P., Cousins, B., 2013. In the Shadow of Policy: Everyday Practices in South African Land and Agrarian Reform. Wits University Press, Johannesburg, South Africa.

Hebinck, P., Mango, N., Kimanthi, H., 2015a. Local maize practices and the cultures of seed in Luoland, West Kenya. In: Dessein, J., Battaglini, E., Horlings, L. (Eds.), Cultural Sustainability and Regional Development: Theories and Practices of Territorialisation. Routledge, London, pp. 206-219.

Hebinck, P., Van der Ploeg, J., Schneider, S., 2015b. Rural Development and the Construction of New Markets, ISS Rural Livelihoods Series. Routledge, London.

Hirsch, P., 2012. Reviving agrarian studies in South-East Asia: geography on the ascendancy. Geogr. Res. 50, 393-403.

Hobsbawm, E., 1994. Age of Extremes: the Short Twentieth Century, 1914-1991. Michael Joseph, London.

Holt-Giménez, E., Altieri, M., 2012. Agroecology, food sovereignty and the new Green revolution. J. Sustain. Agric. 37120904081412003.

Hull, E., 2014. The social dynamics of labor shortage in South african small-scale agriculture. World Dev. 59, 451-460.

International Labour Office, 2010. Global Employment Trends. ILO, Geneva.

International Labour Office, 2016. World Employment and Social Outlook for Youth 2016. ILO, Geneva.

Kinsella, J., Wilson, S., Jong, F., de Renting, H., 2000. Pluriactivity as a livelihood strategy in Irish farm households and its role in rural development. Sociol. Rural. 40, 481-496 (416).

Kydd, J., Dorward, A., 2001. The Washington consensus on poor country agriculture: analysis, prescription and institutional gaps. Dev. Pol. Rev. 19, 467-478.

Lang, T., 2010. Crisis? What Crisis? The normality of the current food crisis. J. Agrar. Change 10, 87-97.

Latour, B., 2005. Reassembling the Social: an Introduction to Actor-network-theory. Oxford University Press, Oxford.

Leavy, J., Hossain, N., 2014. Who Wants to Farm? Youth Aspirations, Opportunities and Rising Food Prices, vol 2014 Institute for Development Studies, University of Sussex
Working Paper, No 439.

Li, T., 2007. Practices of assemblage and community forest management. Econ. Soc. 36, 263-293.

Li, T., 2009. Exit from agriculture: a step forward or a step backward for the rural poor? J. Peasant Stud. 36, 629-636.

Li, T., 2014. What is land? Assembling a resource for global investment. Trans. Inst. Br. Geogr. 39, 589-602.

Long, N., 2001. Development Sociology: Actor Perspectives. Routledge, London.

Louw, A., Vermeulen, H., Kirsten, J., Madevu, H., 2007. Securing small farmer participation in supermarket supply chains in South Africa. Dev. South Afr. 24, 539-551.

Lowder, S., Skoet, J., Raney, T., 2016. The number, size, and distribution of farms, smallholder farms, and family farms worldwide. World Dev. 87, 16-29.

Manyelo, K., Van Averbeke, W., Hebinck, P., 2015. Fields, Roads and Streets: Petty Fresh produce Production and Trade in Thohoyandou, South Africa, Rural Development and the Construction of New Markets. Routledge, London, pp. 131-148.

Margulis, M., McKeon, N., Borras, S., 2013. Land grabbing and global governance: critical perspectives. Globalizations 10, 1-23.

Marongwe, N., Mavedzenge, B., Mahenehene, J., Murimbarimba, F., Sevilla Guzmán, E., Woodgate, G., 2012. Agroecology: foundations in agrarian social thought and sociological theory. Agroecology and Sustainable Food Systems 37, 32-44.

Marsden, T., 1998. Agriculture beyond the treadmill? Issues for policy, theory and research practice. Prog. Hum. Geogr. 22, 265-275.

Marsden, T., 2003. The Condition of Rural Sustainability. Royal Van Gorcum, Assen.

Marsden, T., 2016. Re-placing neo-liberalism? Exploring more sustainable governance pathways for agri-food and rural development. In: Bevir, M. (Ed.), Governmentality after Neo-liberalism: the British Experience. Routledge, London, pp. 75-87.

Martínez-Torres, M., Rosset, P., 2010. La Vía Campesina: the birth and evolution of a transnational social movement. J. Peasant Stud. 31, 149-175.

McFarlane, C., 2009. Translocal assemblages: space, power and social movements. Geoforum 40, 561-567.

McMichael, P., 2008. Peasants make their own history, but not just as they please.... J. Agrar. Change 8, 205-228.

McMichael, P., 2012. Depeasantization, the Wiley-Blackwell Encyclopedia of Globalization. John Wiley \& Sons, Ltd, Chichester; New York, pp. 681-701.

McMichael, P., 2013. Food Regimes and Agrarian Questions. Fernwood Publishing, Halifax.

Milone, P., Fuller, T., Ventura, F., Van der Ploeg, J.D., Marsden, T., Schneider, S., Ye, J., Carolan, M., Scott, S., Monllor I Rico, N., 2018. Book Review. Constructing a New Framework for Rural Development, P. Milone, F. Ventura and J. Ye (eds) (2015). 338 pp., Research in Rural Sociology and Development Vol. 22, Emerald UK, ISBN: 978-178441-622-5. Journal of Rural Studies 57, 78-87.

Milone, P., Ventura, F., 2010. Networking the Rural, the Future of Green Regions in Europe. Royal Van Gorcum, Assen.

Milone, P., Ventura, F., Ye, J., 2015. Constructing a New Framework for Rural Development, Sociology and Development. Emerald, London.

Mousseau, F., 2016. The untold success story of agroecology in Africa. Development 1-5.

Mutopo, P., 2011. Women's struggles to access and control land and livelihoods after fast track land reform in Mwenezi District, Zimbabwe. J. Peasant Stud. 38, 1021-1046.

Mutopo, P., 2014. Women, Mobility and Rural Livelihoods in Zimbabwe: Experiences of Fast Track Land Reform. Brill Academic Publishers.

Nelson, J., Stock, P., 2018. Repeasantisation in the United States. Sociol. Rural. 58, 83-103.

Oostindie, H., 2015. Family Farming Futures. Agrarian Pathways to Multifunctionality: Flows of Resistance, Redesign and Resilience. Unpublished PhD Thesis Rural Sociology. Wageningen University, Wageningen.

Olivier de Sardan, J.P., 2006. Anthropology and Development: Understanding Contemporary Social Change. Zed Press, London.

Otsuka, K., Place, F., 2001. Land Tenure and Natural Resource Management: a Comparative Study of Agrarian Communities in Asia and Africa. Johns Hopkins University Press, Baltimore, MD.

Oya, C., 2012. Contract farming in sub-saharan Africa: a survey of approaches, debates and issues. J. Agrar. Change 12, 1-33.

Pasmans, T., Hebinck, P., 2017. Rural development and the role of game farming in the Eastern Cape, South Africa. Land Use Pol. 64, 440-450.

Patel, R., 2007. Stuffed and Starved: Markets, Power and the Hidden Battle for the World Food System. Portobello Books, London.

Peemans, J.P., 2013. A Political Economy of Rural Development in South East Asia in Relation with the Many Versions of the Disappearance of the Peasantry. Etudes et Documents du Groupe de Recherches Asie de l'Est et du Sud-Est, Louvain. pp. 104.

Peters, P., 2013. Conflicts over land and threats to customary tenure in Africa. Afr. Aff. $112,543-562$.

Proctor, F., Lucchesi, V., 2012. Small-scale Farming and Youth in an Era of Rapid Rural Change. IIED/HIVOS, London, The Hague.

Ramisch, J., 2014. 'We will not farm like our fathers did'. Multilocational livelihoods, cellphones, and the continuing challenge of rural development in western Kenya. In: Sick, D. (Ed.), Rural Livelihoods, Regional Economies, and Processes of Change. Routledge, London, pp. 1-25.

Rasmussen, L., Reenberg, A., 2015. Multiple outcomes of cultivation in the Sahel: a call for a multifunctional view of farmers' incentives. International Journal of Agricultural Sustainability Science 13, 1-22.

Reardon, T., Henson, S., Bèrdegue, J., 2007. "Proactive fast-tracking" diffusion of supermarkets in developing countries: implications for market institutions and trade. J. Econ. Geogr. 7, 399-431.

Reardon, T., Timmer, C., Minten, B., 2012. Supermarket revolution in Asia and emerging development strategies to include small farmers. Proc. Natl. Acad. Sci. Unit. States Am. 109, 12332-12337. 
Rigg, J., 2005. Poverty and livelihoods after full-time farming: a South-East Asian view. Asia Pac. Viewp. 46, 173-184.

Rigg, J., 2006. Land, farming, livelihoods, and poverty: rethinking the links in the Rural South. World Dev. 34, 180-202.

Rigg, J., Nattapoolwat, S., 2001. Embracing the global in Thailand: activism and pragmatism in an era of de-agrarianisation. World Dev. 29, 945-960.

Rigg, J., Salamanca, A., Thompson, E., 2016. The puzzle of East and Southeast Asia's persistent smallholder. J. Rural Stud. 43, 118-133.

Roep, D., Van der Ploeg, J., 2003. Multifunctionality and rural development: the actual situation in Europe. In: Van Huylenbroeck, G., Durand, G. (Eds.), Multifunctional Agriculture. A New Paradigm for European Agriculture and Rural Development. Ashgate, New Hampshire, pp. 37-53.

Rosset, P., 2013. Re-thinking agrarian reform, land and territory in La via Campesina. J. Peasant Stud. 40, 721-775.

Rosset, P., Patel, R., Courville, M., 2006. Promised Land: Competing Visions of Agrarian Reform. Food First Books, Oakland CA.

Samberg, L., Gerber, J., Ramankutty, N., Herrero, M., West, P., 2016. Subnational distribution of average farm size and smallholder contributions to global food production. Environ. Res. Lett. 11, 124010.

Schneider, S., Salvate, N., Cassol, A., 2016. Nested markets, food networks, and new pathways for rural development in Brazil. Agriculture 6, 61.

Schultz, T.W., 1964. Transforming Traditional Agriculture. Yale University Press, New Haven.

Scoones, I., Marongwe, N., Mavedzenge, B., Mahenehene, J., Murimbarimba, F., Sukume, C., 2010. Zimbabwe's Land Reform. Myths \& Realities. James Currey, Oxford.

Scoones, I., Marongwe, N., Mavedzenge, B., Murimbarimba, F., Mahenehene, J., Sukume, C., 2012. Livelihoods after land reform in Zimbabwe: understanding processes of rural differentiation. J. Agrar. Change 12, 503-527.

Sender, J., Johnston, D., 2004. Searching for a weapon of mass production in rural Africa: unconvincing arguments for land reform. J. Agrar. Change 4, 142-164.

Sevilla Guzmán, E., Woodgate, G., 2012. Agroecology: foundations in agrarian social thought and sociological theory. Agroecology and Sustainable Food Systems 37, 32-44.

Shackleton, S., Shackleton, C., 2015. Not just farming: natural resources and livelihoods in land and agrarian reform. In: Cousins, B., Walker, C. (Eds.), Land Divided, Land Restored: Land Reform in South Africa for the 21st Century. Jacana, Auckland Park, pp. 191-205.

Snipstall, B., 2015. Repeasantization, agroecology, and the tactics of food sovereignty. Canadian Food Studies 2, 164-173.

Stiglitz, J., 1998. Towards a New Paradigm for Development: Strategies, Policies and Processes. UN, Geneva.

Stiglitz, J.E., 2002. Globalization and its Discontents. Allen Lane, London.

Suess-Reyes, J., Fuetsch, E., 2016. The future of family farming: a literature review on innovative, sustainable and succession-oriented strategies. J. Rural Stud. 47 (Part A), 117-140.

Thiesenhusen, W., 1995. Broken Promises. Agrarian Reform and the Latin American Campesino. Westview Press, Boulder CO.

Toledo, V.M., 1990. The ecological rationality of peasant production. In: Altieri, M., Hecht, S. (Eds.), Agroecology and Small Farm Development. CRC Press, Boca Raton, pp. 53-61.

Tsing, A., 2000. The global situation. Cult. Anthropol. 15, 327-360.

Twyman, C., Sporton, D., Thomas, D., 2004. 'Where is the life in framing?': the viability of smallholder farming on the margins of the Kalahari, Southern Africa. Geoforum 35, 69-85.

Umans, L., Arce, A., 2014. Fixing rural development cooperation? Not in situations involving blurring and fluidity. J. Rural Stud. 34, 337-344.

Van den Berg, L., Hebinck, P., Roep, D., 2018. 'We go back to the land': processes of repeasantisation in Araponga, Brazil. J. Peasant Stud. 45, 653-675.

Vandermeer, J., Perfecto, I., 2012. Complex traditions: intersecting theoretical frameworks in agroecological research. Agroecology and Sustainable Food Systems 37, 76-89.

Van der Ploeg, J.D., 2006. Agricultural production in crisis. In: Cloke, P., Marsden, T. Mooney, P. (Eds.), Handbook of Rural Studies. Sage, London, pp. 258-277.

Van der Ploeg, J.D., 2008. The New Peasantries. Struggles for Autonomy and Sustainability in an Era of Empire and Globalization. Earthscan, London.

Van der Ploeg, J.D., 2010a. The food crisis, industrialized farming and the imperial regime. J. Agrar. Change 10, 98-106.

Van der Ploeg, J.D., 2010b. The peasantries of the twenty-first century: the commoditisation debate revisited. J. Peasant Stud. 37, 1-30.

Van der Ploeg, J.D., 2013. Peasants and the Art of Farming. A Chayanovian Manifesto. Fernwood Publishers, Nova Scotia.

Van der Ploeg, J.D., 2014. Peasant-driven agricultural growth and food sovereignty. J. Peasant Stud. 41, 999-1030.

Van der Ploeg, J.D., 2016. Theorizing agri-food economies. Agriculture 6.

Van der Ploeg, J.D., 2017. Differentiation: old controversies, new insights. J. Peasant Stud. 1-36.

Van der Ploeg, J.D., Jingzhong, Y., Schneider, S., 2012. Rural development through the construction of new, nested, markets: comparative perspectives from China, Brazil and the European Union. J. Peasant Stud. 39, 113-173.

Van der Ploeg, J.D., Franco, J., Borras, S., 2015. Land concentration and land grabbing in Europe: a preliminary analysis. Can. J. Dev. Stud./Rev. Can. Études Dev. 36, $147-162$.

Vanhaute, E., 2011. From famine to food crisis: what history can teach us about local and global subsistence crises. J. Peasant Stud. 38, 47-65.

Vanhaute, E., 2012. Peasants, peasantries and (de) peasantization in the capitalist worldsystem. In: Babones, S., Chase-Dunn, C. (Eds.), Routledge Handbook of World-systems Analysis. Routledge, London, pp. 313-321.

Veldwisch, G., 2015. Contract farming and the reorganisation of agricultural production within the Chókwè Irrigation System, Mozambique. J. Peasant Stud. 1-26.

Wallerstein, I., 1974. The Modern World-system: Capitalist Agriculture and the Origins of the European World-economy in the Sixteenth Century. Univ of California Press, Berkley LA.

Weatherspoon, D., Reardon, T., 2003. The rise of supermarkets in Africa: implications for agrifood systems and the rural poor. Dev. Pol. Rev. 21, 333-355.

Wegner, L., Zwart, G., 2011. Who Will Feed the World? the Production Challenge. Oxfam Research report. Oxfam, London.

Wezel, A., Bellon, S., Doré, T., Francis, C., Vallod, D., David, D., 2009. Agroecology as a science, a movement and a practice. A review Agronomy for Sustain. Development 29, 503-515.

Wezel, A., Soboksa, G., McClelland, S., Delespesse, F., Boissau, A., 2015. The blurred boundaries of ecological, sustainable, and agroecological intensification: a review. Agron. Sustain. Dev. 35, 1283-1295.

White, B., 2012a. Changing childhoods: Javanese village children in three generations. J. Agrar. Change 12, 81-97.

White, B., 2012b. Agriculture and the generation problem: rural youth and the future of farming. IDS Bull. 43, 9-19.

Woods, M., 2007. Engaging the global countryside: globalization, hybridity and the reconstitution of rural place. Prog. Hum. Geogr. 31, 485-507.

Woods, M., 2014. Family farming in the global countryside. Anthropol. Noteb. 20, 31-48.

Woods, M., 2015. Territorialisation and the assemblage of rural place: examples from Canada and New Zealand. In: Dessein, J., Battaglini, E., Horlings, L. (Eds.), Cultural Sustainability and Regional Development: Theories and Practices of Territorialisation. Routledge, London, pp. 29-43.

Zoomers, A., 2001. Land and Sustainable Livelihood in Latin America. Royal Tropical Institute, KIT Publishers, Amsterdam.

Zoomers, A., 2010. Globalisation and the foreignisation of space: seven processes driving the current global land grab. J. Peasant Stud. 37, 429-447.

Paul Hebinck ${ }^{\mathrm{a}, \mathrm{b}, *}$
a Wageningen University, Department of Social Sciences - Sociology of
Development and Change Hollandseweg 1, Wageningen $6706 \mathrm{KN}$, The
Netherlands
b University of Fort Hare, Department of Agricultural Economics and
Extension, 1 King Williams Town Road, Alice 5700, South Africa
E-mail address: paul.hebinck@wur.nl

${ }^{\text {a }}$ Wageningen University, Department of Social Sciences - Sociology of

University of Fort Hare, Department of Agricultural Economics and E-mail address: paul.hebinck@wur.nl 